\title{
Assessment of Small Pelagic Species Landed in ARMM, Sulu Sea
}

\author{
Macmod D. Mamalangkap ${ }^{1}$, Usop K. Mokamad ${ }^{1}$, Sammy M. Ayub ${ }^{1, \star}$ \\ ${ }^{1}$ Bureau of Fisheries and Aquatic Resources - Autonomous Region in Muslim Mindanao \\ ORG Compound, 9600 Cotabato City
}

\section{A B S T R A C T}

The purpose of this study is to provide a general information of fisheries in the provinces of Basilan, Sulu, and Tawi-Tawi, of the Autonomous Region in Muslim Mindanao (ARMM) covering the period from CY 2008 to 2012 which can be a basis for the formulation of fisheries management geared towards protection, preservation, utilization, and development of ARMM waters as embodied in Section 2 of the Implementing Rules of the ARMM Muslim Mindanao Autonomy Act (MMAA) No. 86.

The number of boats and gears were obtained from the monitored data of NSAP. Catch and CPUE were analyzed using MS Excel. Seasonality of species was processed by extracting information on landed catch from the NSAP data and the high and low catch by month were then analyzed.

Tunas and oceanic pelagic are abundant finfishes in the Sulu Sea. The catch composition was dominated by neritic and oceanic tunas with Euthynus affinis representing $35.20 \%$ of the total catch, followed by Katsuwonus pelamis with 29.22\%, and Auxis thazard with $5.44 \%$.

Five small pelagic species such as Selar crumenophthalmus, Sardinella lemuru, Rastrelliger kanagurta, Auxis thazard, and Decapterus macrosoma were analyzed for seasonality and the results showed that these species commonly peaked in terms of catch during the 1st and 2nd quarters of every year from CY 2008 to CY 2012. Population parameter values $\left(\mathrm{K}\right.$ and $\mathrm{L}_{\infty}$ ) of the selected species were found to be within the values given in FishBase. The length frequency distribution of selected small pelagic species shows a situation of growth overfishing since they were caught at sizes before their length at first maturity (Lm). Estimates of fishing mortality and exploitation rates for most of the species analyzed were found to have exceeded the Eopt level.

^E-mail:sammyayub@ymail.com

Received: 1 February 2017

Accepted: 10 July 2017
Keywords: fisheries management, CPUE, seasonality, neritic and oceanic tuna, pelagics, Sulu Sea

\section{REVIEW OF RELATED LITERATURE}

The growing concern for resource assessment was strongly motivated in the mid-1900s where anecdotal evidence seemed to prove a declining fish stocks in major fishing grounds in the world. The objective of the assessment is focused on knowing the status of fisheries and how proper management can be put in place.

In 1994, BFAR with the assistance from the International Center for Living Aquatic Resources Management (ICLARM) embarked in a project with an end-in-view of analyzing the available data and to publish an atlas of growth parameters of different fish species.

The Philippine coastal environment with its extensive shoreline, marked by mangrove areas and river connections, coral reefs, and seagrass communities has been known to harbor a great variety of fishes. Interestingly, the Philippines is the epicenter of marine biodiversity with the richest concentration of marine life in the entire planet (Carpenter and Springer 2005).

The variety of fishes in the Philippines that have been identified so far is comprised of 2,145 species (Herre
1953) which have been given different names by every region and by major dialects in the country. Today, about 2,824 marine fish species are listed at FishBase.

\section{LIMITATION OF THE STUDY}

This study was not able to present an estimate of the Maximum Sustainable Yield (MSY) for the Sulu Sea. The MSY is an estimate of the Total Allowable Catch (TAC) that should be harvested or taken out from a fishing ground in order to sustain its fisheries resources.

The Sulu Sea is a shared fishing ground for Regions IX and ARMM, aside from the fact that there are also fishing vessels from other regions which are doing fishing activities in the Sulu Sea. This scenario sets a limit for ARMM and Region IX in coming up with an estimate of MSY for the Sulu Sea because these two regions have their own data distinct from each other. Both regions cannot have their own and respective values of MSY for one fishing ground. There has to be a merging of data by these two regions before an estimate of MSY can be drawn out. 
The results presented in this study reflect only the fishery status of Sulu Sea based on the data of the National Stock Assessment Program in the ARMM which can be a basis of any fisheries management in the future. However, it may not necessarily mean to show the fisheries status of the whole of Sulu Sea.

\section{I N T R O D U C T I O N}

$\mathbf{T}$ The Autonomous Region in Muslim Mindanao (ARMM) was created on August 1, 1989 by virtue of Republic Act No. 6734 entitled "AN ACT PROVIDING FOR THE ARMM". It is located southwest of the Philippines, about 120-124 degrees $\mathrm{N}$ and 80-50 degrees E. It has a vast territorial water area of 18,426,613 ha., shelf area of 2,811,141.07 ha., coastline (length) of $3,232.29 \mathrm{~km}^{2}$, and a land area of $33,891.9 \mathrm{~km}^{2}$.

Fisheries Stock Assessment is essential as it can give information that can be used in the proper management of our fisheries resources. It is an effective tool in which people will become aware of the current situation of our fish stocks.

Presently, there is a growing global concern on fisheries. There are already published researches and literature from different sectors of our society-all gearing towards providing vital information from what is beneath our seas.

In the Philippines, assessment of the status of

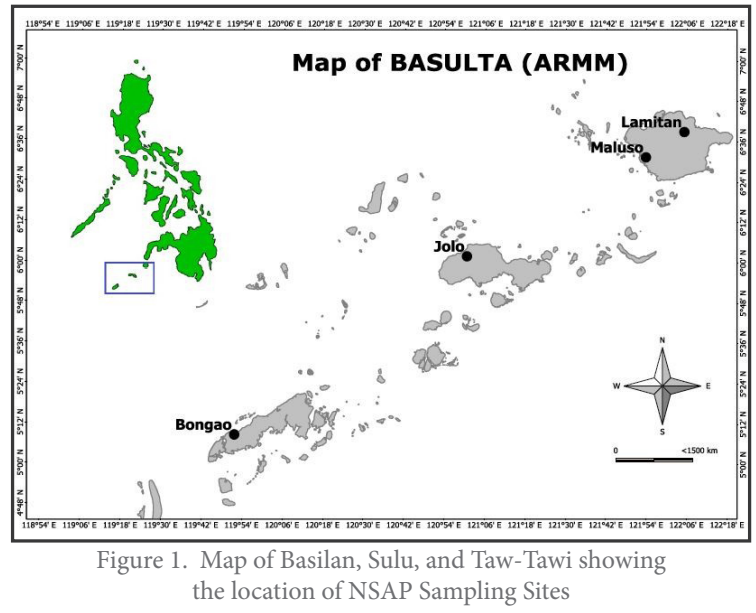

fisheries resources continues to capture the interest of our people. To further deepen our knowledge of fisheries resources, the government has funded the National Stock Assessment Program to conduct an independent assessment of our fishing grounds in the country using modern and scientific approaches.

In 1998, the National Stock Assessment Program (NSAP) officially took off and from then on to the present scientific data are being gathered from all over the country. The birth of NSAP is a great opportunity for ARMM since there are few published studies that deal with the assessment of fisheries resources in the region.

Going parallel with the endeavors of the National
Fisheries Research and Development Institute (NFRDI) thru the National Stock Assessment Program (NSAP), the NSAP-ARMM has come up with this technical paper with hope of bringing out responsible and reliable scientific information for the management, utilization, protection, and preservation of the fisheries resources in the Autonomous Region in Muslim Mindanao.

We hope that this Technical Paper can serve as a basis and guide for people who have the heart to protect and preserve our fisheries resources.

May Allah (S.W.T.) Bless Us All.

\section{OBJECTIVES OF THE STUDY}

\section{General:}

a. Generate information for the management of important fish stocks in the area; and

b. Generate information to support policies for the management of the fishing ground.

Specific: To determine the following:

a. catch and CPUE trends;

b. species composition;

c. catch composition and relative abundance;

d. length frequency distribution;

e. population parameters such as length infinity, growth, and mortality; and

f. exploitation values of selected species.

\section{NSAP - ARMM LANDING/ S A M P L IN G S T ES}

Tawi-Tawi is an island province of the ARMM. It is located in the southernmost part of the country sharing sea borders with the Malaysian State of Sabah and the Indonesian Kalimantan province. Agriculture, fishing, and agar-agar farming are the leading source of livelihood of the people of Tawi-Tawi.

There are 94 fish landing centers in Tawi-Tawi. Among these, two major landing centers were identified as study sites for NSAP sampling activities in the province. These two landing/study site of NSAP are the Mampalan, Public Market, and the Bongao, Tawi-Tawi Fish port. However, starting 2011 to present, only one NSAP study site was continually monitored that is in Bongao Public Market.

Sulu is an island province of the ARMM. Its capital is Jolo, the $15^{\text {th }}$ largest island of the Philippine Archipelago in terms of area, spanning around 1,600 square kilometers

The province of Sulu is predominantly agricultural with farming and fishing as its main livelihood activities. Fishing is the most important industry since the Sulu Sea is one of the richest fishing grounds in the country.

There are a total of 15 landing centers in Sulu 
Table 1. NSAP Sampling schedules during a month.

\begin{tabular}{|c|c|c|c|c|c|c|}
\hline \multicolumn{7}{|c|}{ Month } \\
\hline Mon & Tues & Wed & Thu & Fri & Sat & Sun \\
\hline 1 & 2 & 3 & 4 & 5 & 6 & 7 \\
\hline 8 & 9 & 10 & 11 & 12 & 13 & 14 \\
\hline 15 & 16 & 17 & 18 & 19 & 20 & 21 \\
\hline 22 & 23 & 24 & 25 & 26 & 27 & 28 \\
\hline 29 & 30 & \multicolumn{7}{|c}{} \\
\cline { 1 - 7 }
\end{tabular}

Legend: Yellow - Sampling Day for Commercial Green - Sampling Day for Municipal White - Rest Day

and the National Stock Assessment Program (NSAP) is conducting its sampling/study activities in Serrantes Public Market.

Basilan is an island province of the ARMM. It is the largest and northernmost of the major island of the Sulu Archipelago and is located just off the southern coast of Zamboanga Peninsula.

Fishing is one of the main sources of livelihood in Basilan. There are about fifty-one (51) landing centers identified in the province. The NSAP is conducting its sampling activities on the major fishing grounds, namely Upper Port, Holland in Maluso and Oval Fishing Wharf in Lamitan.

\section{M E T H O D O L O G Y}

\section{Data Collection}

The National Stock Assessment Program is adopting a scientific approach in data gathering through its sampling sites in the entire country.

For its data collection activity, there are two enumerators assigned for every province to conduct sampling activities such as recording, measuring, and weighing of samples. NSAP sampling activities cover the two fisheries sectors which are the commercial and the municipal fisheries sectors. Every first day of the calendar month falls for the commercial fisheries sampling activities, the second day for the municipal fisheries and thereafter including weekdays and holidays for a total of 21 sampling days every month for the commercial and municipal sectors (Table 1).

Collection of data is done every morning on the scheduled dates. Interviews of master fishermen are conducted by the enumerators with emphasis particularly on the site of the fishing operation, the number of hauls, and hours spent per fishing operation. From every fishing gear sampled, fish species are taken at random as samples for length and weight measurements. The length of the fish is measured from the tip of the snout to the end of the caudal fin. For tuna species and other hard-tailed species, length is measured from the snout to the caudal fork. All data and information collected for every sampling day are recorded in the NSAP forms and submitted monthly to the NSAP Regional Office for review, encoding, and processing.

\section{Data Processing and Analysis}

\section{Length Frequency}

Monthly reports of enumerators are encoded using Excel file to get the catch and effort, species composition, length frequency, and weight measurement. After encoding, the data undergo a process of sorting, filtering, and error tracking as part of the quality control being observed in the NSAP. After which, data are then processed/generated using the pivoting feature of the MS Excel.

The length frequencies of the species encoded were raised in each sampling day using the equation:

$$
\mathrm{Rf}=\frac{\text { Total weight of species measured }}{\text { Total weight landed }}
$$

\section{Population parameters}

This study uses the routines found in the FAOICLARM Stock Assessment Tools (FISAT) software (Gayanilo et al. 1996) in obtaining the population parameters

Preliminary estimates of $\mathrm{L}_{\infty}$ (asymptotic length) were obtained from the Powell-Wetherall Plot (Gayanilo and Pauly 1997) using the Beverton and Holt (1956) equation:

$$
\mathrm{Z}=\mathrm{k}\left(\left(\mathrm{L}_{\infty}-\mathrm{L}\right) /\left(\mathrm{L}-\mathrm{L}^{\prime}\right)\right)
$$

Where:

$\mathrm{Z}=$ instantaneous mortality;

$\mathrm{k}$ = growth coefficient;

$\mathrm{L}=$ mean length

$\mathrm{L}_{\infty}=$ asymptotic length;

$\mathrm{L}^{\prime}=$ initial length of sample.

The estimated asymptotic length $\left(\mathrm{L}_{\infty}\right)$ were further processed via K-scan routine, response surface analysis, and automatic search of the Electronic Length Frequency Analysis (Brey and Pauly 1986), wherein the $\mathrm{K}$-value is chosen to provide the "best fit" for the available length-frequency data.

Mortalities and exploitation rates were calculated using the equation: $\mathrm{Z}=\mathrm{M}+\mathrm{F}$

Where:

$$
\begin{aligned}
& Z=\text { total mortality; } \\
& M=\text { natural mortality; } \\
& \mathrm{F}=\text { fishing mortality. }
\end{aligned}
$$

Exploitation rate was then computed using the equation: $\mathrm{E}=\mathrm{F} / \mathrm{Z}$.

Estimation of the probabilities of capture 
Table 2. Number of sampled major and minor gears landed in NSAP Sampling Sites in the provinces of Basilan, Sulu and Tawi-Tawi.

\begin{tabular}{|c|c|c|c|c|c|c|c|c|}
\hline \multirow{3}{*}{ Year } & \multicolumn{6}{|c|}{ Major Gears } & \multirow{3}{*}{$\begin{array}{c}\text { Minor Gears } \\
\text { Municipal } \\
\text { BSGN, BSLL,SG, FP, Etc. }\end{array}$} & \multirow{3}{*}{ TOTAL } \\
\hline & \multicolumn{2}{|c|}{ Commercial } & \multicolumn{4}{|c|}{ Municipal } & & \\
\hline & $\mathrm{RN}$ & $\mathrm{BN}$ & GN & $\mathrm{HL}$ & MHL & DGN & & \\
\hline 2008 & 95 & 18 & 124 & 150 & 157 & 77 & 97 & 718 \\
\hline 2009 & 71 & 40 & 97 & 75 & 72 & 60 & 67 & 482 \\
\hline 2010 & 67 & 89 & 121 & 87 & 38 & 158 & 190 & 750 \\
\hline 2011 & 142 & 81 & 93 & 44 & 92 & 87 & 61 & 600 \\
\hline 2012 & 113 & 108 & 96 & 52 & 39 & 119 & 125 & 652 \\
\hline TOTAL & 488 & 336 & 531 & 408 & 398 & 501 & 540 & 3,202 \\
\hline
\end{tabular}

involves the method of extrapolating the right descending side of the catch curve such that fish that "ought to" have been caught are added to the curve with the ratio of "expected" numbers to those that are actually caught.

\section{RESULTS AND DISCUSSION}

\section{Fishing Boat/Gear}

In fisheries, there are two fishing sectors, commercial and municipal. Commercial fishing is the catching of fishery species by passive or active gear for trade, business, or profit. It is classified as small-scale, medium-scale, or large-scale commercial fishing.

Small-scale commercial fishing refers to fishing with passive or active gears utilizing vessels of 3.1 gross tons (GT) to $20 \mathrm{GT}$. Medium-scale are those fishing vessels with $20.1 \mathrm{GT}$ to $150 \mathrm{GT}$ while large-scale are those with $150.1 \mathrm{GT}$ and up. Most common commercial fishing boats/gears are purse seine, ring net, and bag net.

Municipal fishing refers to fishing within municipal waters using fishing vessels of $3 \mathrm{GT}$ or less or fishing not requiring the use of fishing vessels. Common municipal gears are gill nets, hook and lines, multiple hook and lines, drift gill nets, and others.

Table 2 shows the number of commercial and municipal fishing boats/gears monitored by NSAP in the different NSAP sampling sites from the provinces of Basilan, Sulu, and Tawi-Tawi.

For the commercial fisheries sector, an increasing trend in the number of boats/gears monitored is observed. In ARMM, there are two commercial gears operating and landing at NSAP sampling sites. These are ring net and bag net with the former dominating the commercial gears in terms of the number of units monitored from year 2008 to 2012.

For the municipal sector, gears such as gillnet $(\mathrm{GN})$, hook and line (HK), multiple hook and line (MHL), and drift gill net (DGN) are considered as major municipal gears based on the number of units and frequency of landings per NSAP monitored data. Other municipal gears are bottom set gillnet (BSGN), bottom set longline (BSLL), spear gun (SG), fish pot (FP), and others. From 2008 to 2012, GN, HL, and MHL gears had the highest monitored operation in 2008 while DGN got the highest in 2012. The number of fishing operations vary every year due to many factors that affect the boat operation or the catch rates of every boat. The most common reason that affects the number or frequency of fishing boat operation is weather condition.

\section{Commercial and Municipal Catch Trend and CPUE}

Catch per unit effort (CPUE) is the amount of catch that is taken per unit of fishing gear. It can be used to measure the efficiency of a gear type in terms of catch and also as an index of fish abundance. Theoretically, when effort increases, catch also increases.

Figures 2 and 3 show the annual catch and CPUE trend of commercial gears (ring net and bag net) monitored. Based on the graph, the trend of the CPUE of ring net went parallel with its catch trend, that is when catch increased, CPUE also increased and vice-versa.

For the annual catch and CPUE trend of ring net and bag net, there was a high increase of the CPUE and catch in year 2010. This parallel increase can be an indication of a good fishing situation that may be attributed to many

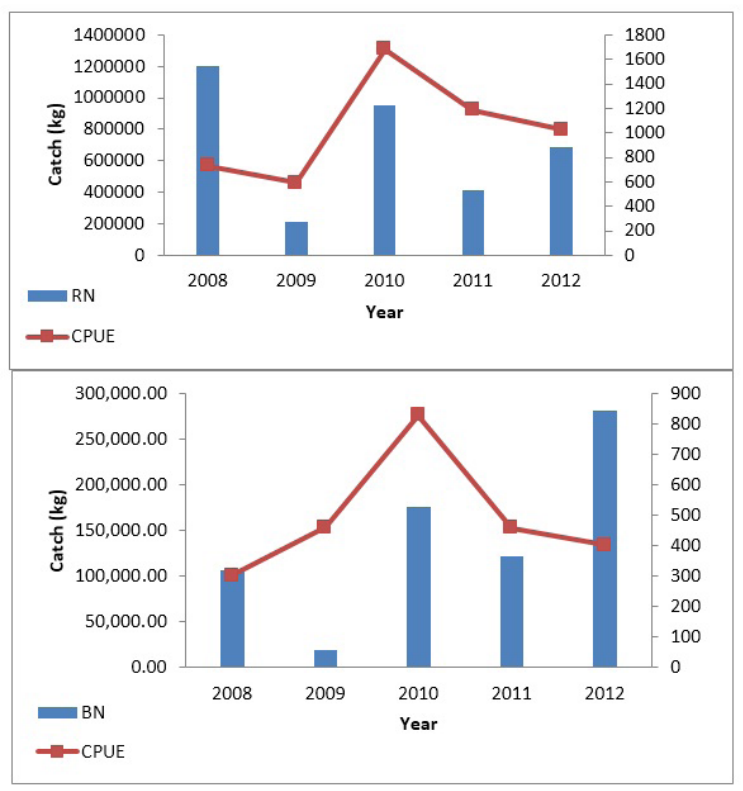

Figure 2. Annual catch and CPUE trend of commercial gears 


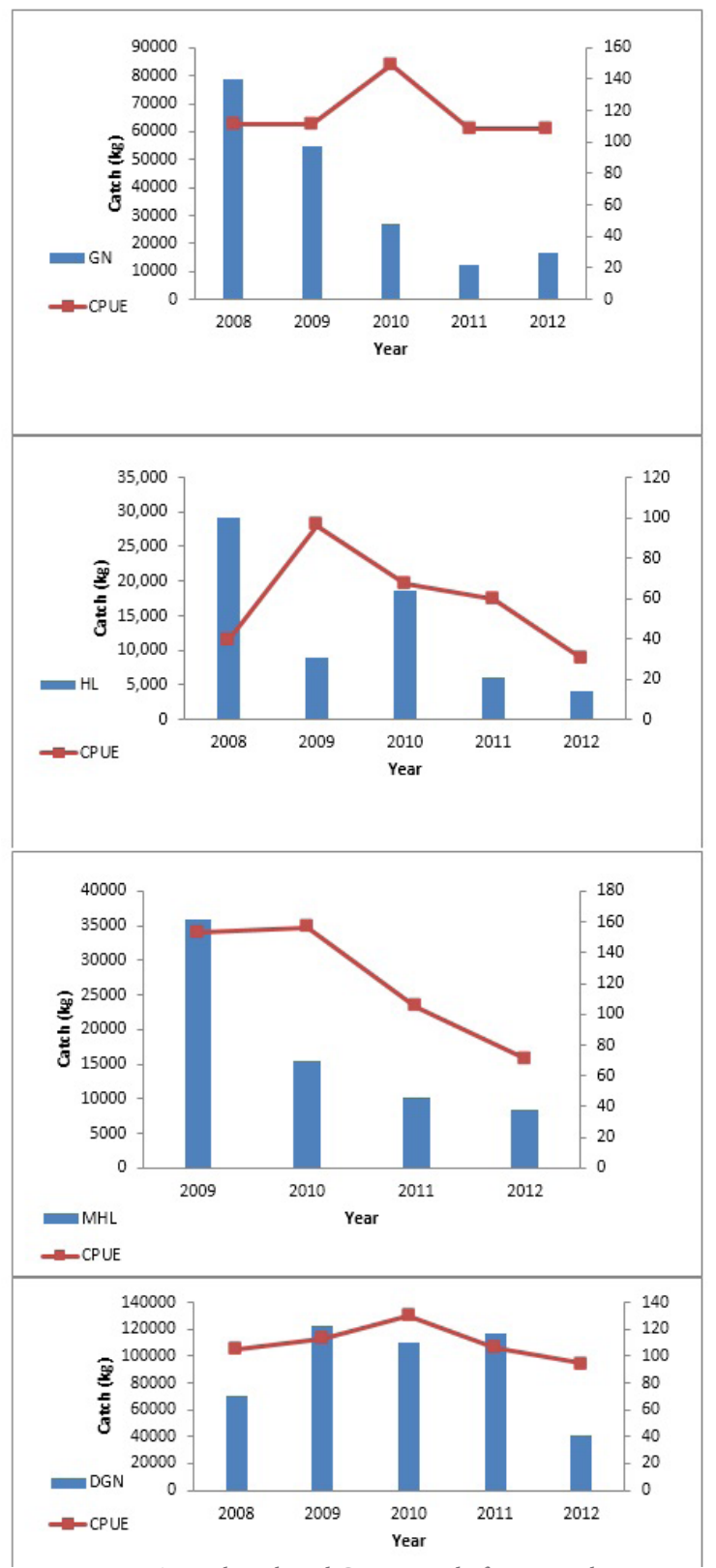

Figure 3. Annual catch and CPUE trend of municipal gears

factors such as good weather conditions or change in fishing strategy and other possible causes. In 2009, there was a decline in catch by both gears while the CPUE of bag net increased in the same year. The situation of bag net gear in 2009 was different as the catch decreased while there was an increase in effort. This situation could be attributed to a declining fish population had it continued to happen in the following years. However, since it only occurred during the year 2009, factors such as a change in fishing operation, gear efficiency, socio-economic factors, and environmental conditions, might be the cause. From CY 2008-2012, both ring net and bag net attained their highest CPUE in CY 2010, an indication of a healthy fishing activity in that year.

For major municipal gears shown in Figures 4 to 7, hook and lines (HL) and multiple hook and lines (MHL) show a decreasing catch and CPUE while nets such as gill net (GN) and drift gillnet (DGN) show a similar CPUE trend although the catch of gillnet has a decreasing trend similar to lines. For nets such as GN and DGN, both attained their highest CPUE in 2010 while HL and MHL similarly had their highest CPUE in 2009.

\section{Species Composition}

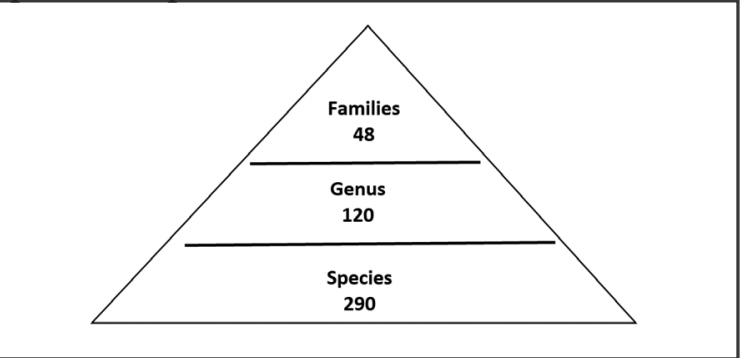

Figure 4. Schematic diagram of the number of fish families, genera, and species identified/caught from Sulu Sea

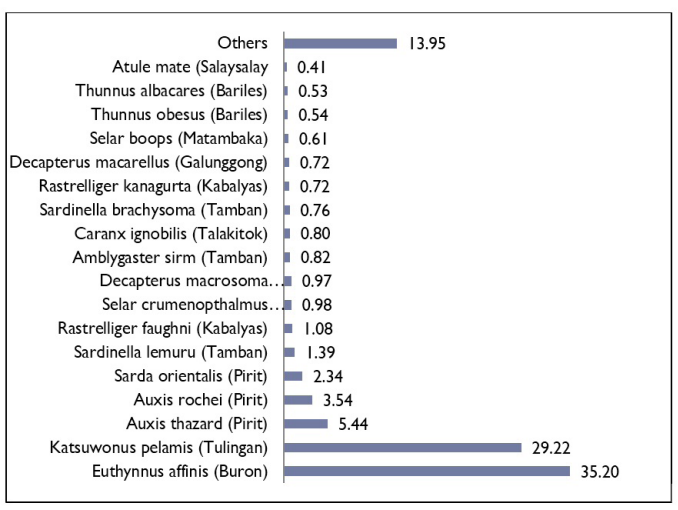

Figure 5. Catch Composition and Relative Abundance

The Sulu Sea is one of the richest fishing grounds in the country. It is home to vast marine resources that include a wide range of marine fishes. In this study, the total species composition was taken from the monitored landed catch in Basilan, Sulu, and Tawi-Tawi by municipal and commercial gears. As shown in Figure 8, there are about 48 families of aquatic fauna, 120 genera, and 290 fish species monitored to have been caught from the Sulu Sea and landed in the NSAP-ARMM sampling sites.

\section{Catch Composition and Relative Abundance of Species Caught by Commercial Gears}

The catch composition and relative abundance were estimated using the catch data from ring net that landed in Basilan, Sulu, and Tawi-Tawi in years 20082012. All species monitored were ranked according to their percentage contribution to the total monitored catch. As shown in Figure 9, the bulk of catch is attributed to Euthynnus affinis which constitutes 35.20 percent, followed by Katsuwonus pelamis with 29.22\%, Auxis thazard with $5.44 \%$, and so on.

There is a higher percentage of catch rate to 


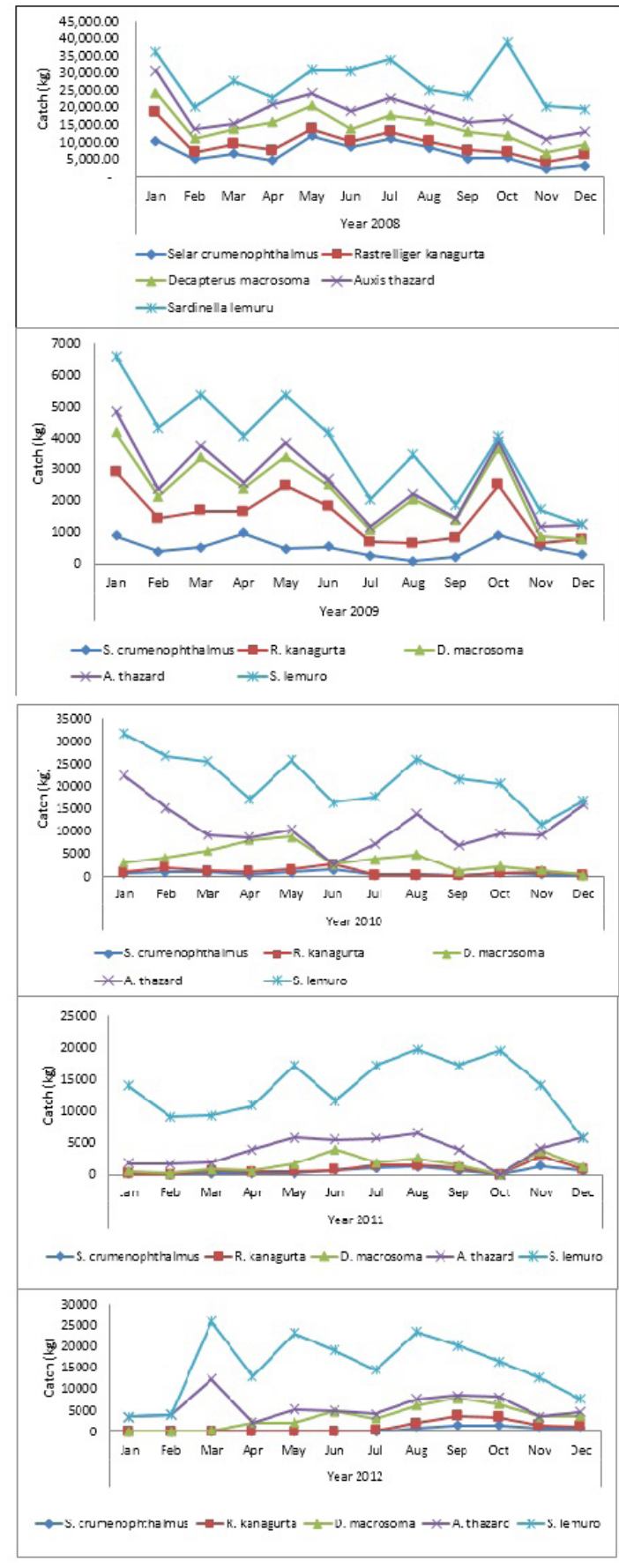

Figure 6. Seasonality

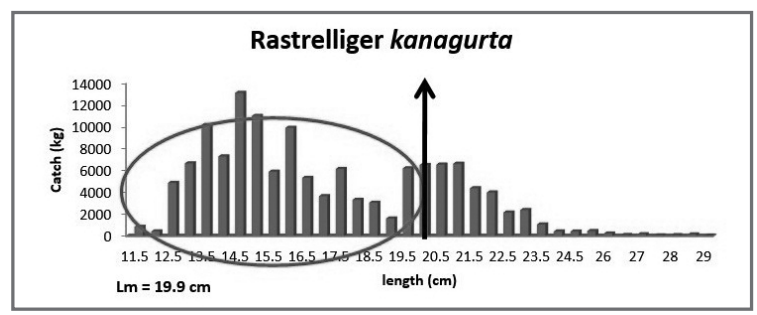

Figure 7A. Length Frequency Distribution of Rastrelliger kanagurta

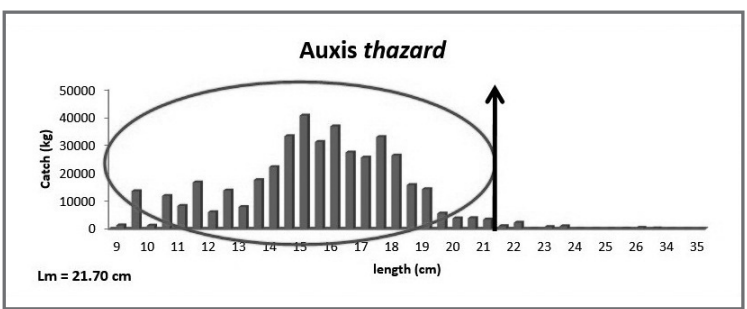

Figure 7B. Length Frequency Distribution of Auxis thazard

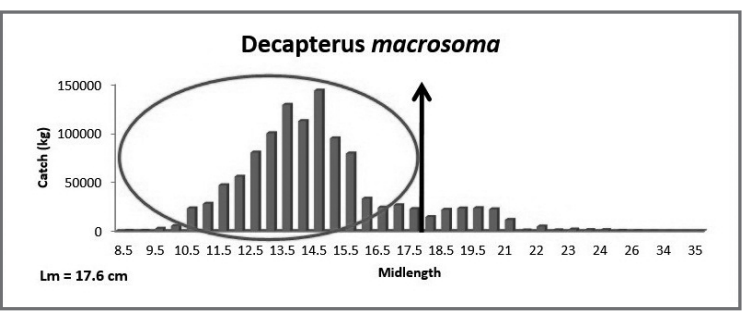

Figure 7C. Length Frequency Distribution of Decapterus macrosoma

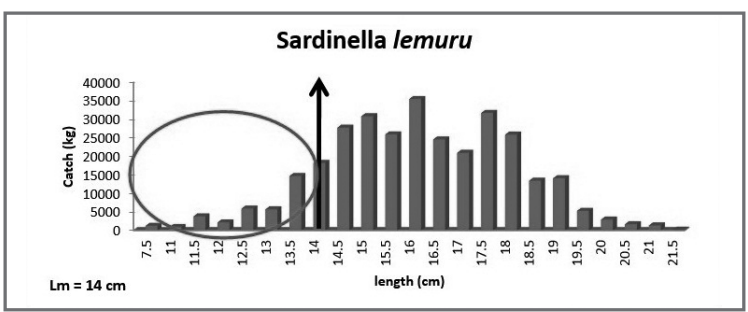

Figure 7D. Length Frequency Distribution of Sardinella lemuru

oceanic tuna like the Katsuwonus pelamis and neritic tunas such as the Euthynnus affinis, Auxis thazard, Auxis rochei, and Sarda orientalis.

Among the three (3) provinces of ARMM that are subject to this study, the above-cited tuna species were mostly monitored in the province of Sulu. The high percentage of tuna catch from the Sulu Sea is an indication that this fishing ground is rich in small fishes, squids, crustaceans, and mollusks because oceanic and neritic tunas feed on these creatures.

\section{Seasonality of Commercially Important Species}

Seasonality refers to a period or month where the highest catch is attained. In this study, five (5) commercially important species were analyzed to determine the months where the highest monitored catch was recorded from 2008 to 2012 (Figures 10-14).

For Selar crumenophthalmus, the highest recorded catch was in the months of April, May June, September, and November. Looking at these months, this species peaks on all months of the 2nd quarter, September of the 3 rd quarter and November of the 4 th quarter of the year.

Rastrelliger kanagurta peaked on the month of January in 2008 and 2012, June of the 2nd quarter, September of the 3rd quarter, and November of the 4 th quarter. 

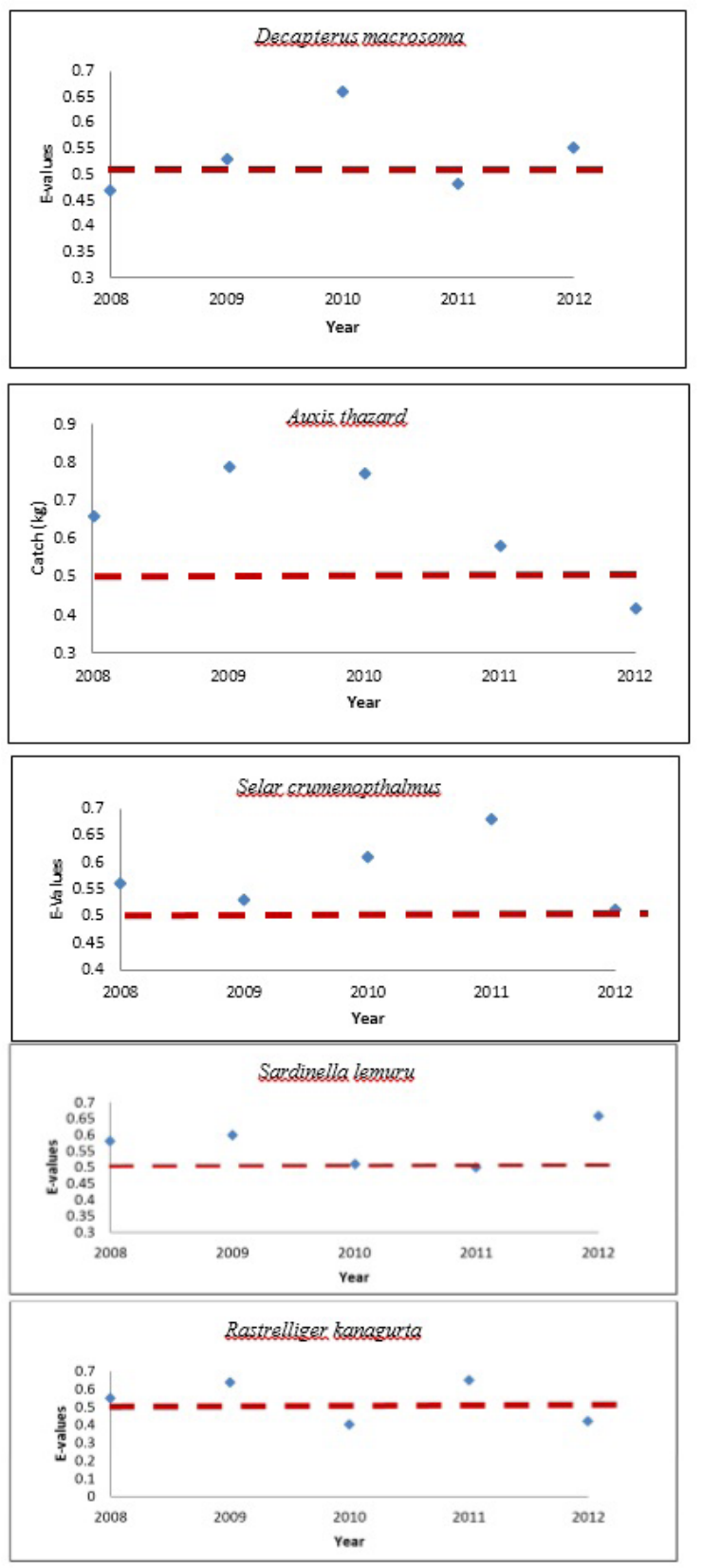

Figure 8. Exploitation Values

Decapterus macrosoma peaked in January, March, May, and June.

Auxis thazard peaked in January, March, October, and December.

Sardinella lemuru peaked in February, March, April, May, and October.

From CY 2008-2009, those five species commonly peaked during 1st and 2nd quarters of every year. Using the Philippine climate as a criterion, catch of the subject species commonly peaks during the Dry Season or "summer season". Using temperature and rainfall as bases, the climate of the country can be divided into two (2) major seasons: Rainy Season (from June to November) and Dry Season (from December to May).

\section{Length Frequency Distribution}

In this analysis, the actual length class of the selected pelagic species was analyzed from the sampled catch landed in Basilan, Sulu, and Tawi-Tawi from 20082012 for both municipal and commercial sectors. For this study, length at first maturity $(\mathrm{Lm})$ values of the selected species were based from the published values given by Froese and Pauly (2004) in the meantime that reproductive biology was not yet undertaken for the said species during the study period.

Length frequency analysis is a practical approach to determining whether or not an overfishing is happening to a particular species or group of species.

As shown in the graph (Figure 7), Selar crumenophthalmus starts to mature at $14.8 \mathrm{~cm}$ and as per sampling record, this species is already caught at length $9.5 \mathrm{~cm}$. Rastrelliger kanagurta with length at first maturity (Lm) of $19.9 \mathrm{~cm}$ starts to be caught as early as $11.5 \mathrm{~cm}$. Sardinella lemuru with $\mathrm{Lm}=14 \mathrm{~cm}$ starts to be caught at $7.5 \mathrm{~cm}$. Decapterus macrosoma with $\mathrm{Lm}=17.6 \mathrm{~cm}$. also started to be caught at $8.5 \mathrm{~cm}$. Auxis thazard with $\mathrm{Lm}=21.70 \mathrm{~cm}$ starts to be caught at $9 \mathrm{~cm}$.

All species analyzed started to be caught before their lengths at maturity $(\mathrm{Lm})$. This is an indication of a growth overfishing. Growth overfishing occurs when fishes are caught at an early stage or before their maturity because they were not given the chance to reproduce and contribute to the biomass. Ideally, any fish should be caught after their maturity stage so that it can reproduce or spawn, thus contributing to the fish population.

\section{Growth Parameters}

Growth parameters refer to estimates of physical and biological characteristics of fish species analyzed. It includes, among others, Length Infinity $\left(\mathrm{L}_{\infty}\right)$, growth rate $(\mathrm{K})$ within a given period, total mortality $(\mathrm{Z})$, natural mortality (M), fishing mortality (F), and exploitation values (E).

Growth parameters of the selected species were analyzed using the FAO-ICLARM Stock Assessment Tools (FISAT II) software (Gayanilo et al. 1996).

Numerical values of growth parameters change over time. This is a normal situation in which interactions in the biodiversity and environmental conditions are some of the contributing factors. Growth parameters differ from species to species, but they may also vary from stock to stock within the same species (i.e., growth parameters of a particular species may take different values in different parts of its range). Also, successive cohorts may grow differently depending on environmental conditions (Sparre and Venema 1992). The values of growth parameters shown in Table 4 are within the range of values given in the published literature (Froese and Pauly 2004). 
Table 3. List of monitored fish species.

\begin{tabular}{|c|c|}
\hline Acanthurus lineatus & Epinephelus bilobatus \\
\hline Acanthurus nigrofuscus & Epinephelus fasciatus \\
\hline Acanthurus blochii & Epinephelus corallicola \\
\hline Acanthurus olivaceous & Epinephelus mera \\
\hline Acanthurus xanthopterus & Epinephelus areolatus \\
\hline Acanthurus dussumieri & Epinephelus quoyanus \\
\hline Alectis ciliaris & Epinephelus rivulatus \\
\hline Alectis indicus & Epinephelus tauvina \\
\hline Arius maculatus & Epinephelus amblycephalus \\
\hline Amblygaster sirm & Epinephelus tukula \\
\hline Aprion virescens & Epinephelus melanostigma \\
\hline Alepes djidaba & Epinephelus sexfasciatus \\
\hline Alepes melanoptera & Epinephelus fuscoguttatus \\
\hline Abudefduf sexfasciatus & Epinephelus diacanthus \\
\hline Arius maculatus & Epinephelus guttatus \\
\hline Abalistes stellaris & Epinephelus merra \\
\hline Atropus atropus & Epinephelus hexagonatus \\
\hline Anguilla japonicus & Epinephelus caeruleopuntatus \\
\hline Atue mate & Epinephelus bleekeri \\
\hline Auxis rochei & Eleutheronema tetradactylum \\
\hline Auxis thazard & Engraulis japonicus \\
\hline Balistoides viridescens & Encrasicholina puntifer \\
\hline Balistapus undulatus & Etelis carbunculus \\
\hline Caesio cuning & Etelis oculatus \\
\hline Caesio lunaris & Euthynnus affinis \\
\hline Caesio striata & Elagatis bipinnulata \\
\hline Carangoides armatus & Gazza minuta \\
\hline Carangoides chrysophrys & Gazza achlamys \\
\hline Carangoides equula & Gymnothorax ocellatus \\
\hline Carangoides ferdau & Gerres filamentosus \\
\hline Carangoides fulviflamma & Gerres oyena \\
\hline Carangoides hedlandensis & Gerres oblongus \\
\hline Carangoides malabaricus & Gerres abbreviatus \\
\hline Carangoides hemorosus & Grammatorcynus bilineatus \\
\hline Carangoides orthogrammus & Gymnocranius griseus \\
\hline Carangoides uii & Gymnocranius griseus \\
\hline Chanos chanos & Gymnocranius microdon \\
\hline Caranx ignobilis & Gymnothorax ocellatus \\
\hline Caranx buccalentus & Gnathanodon speciosus \\
\hline Caranx chrysophrys & Gymnosarda unicolor \\
\hline Cephalopolis miniatus & Grammatorcynus bilineatus \\
\hline Caranx hemorosus & Gymnocranius robinsoni \\
\hline Caranx indicus & Hemiramphus far \\
\hline Caranx isacanthus & Istiophorus platypterus \\
\hline Caranx lugubris & \begin{tabular}{|l|} 
Xiphias gladius \\
\end{tabular} \\
\hline Caranx melampygus & Kyhposus vaigiensis \\
\hline Caranx orthogrammus & Katsuwonus pelamis \\
\hline Caranx para & Leiognathus bindus \\
\hline Caranx papuensis & Leiognathus equulus \\
\hline Caranx sexfasciatus & Leiognathus splendens \\
\hline Caran $x$ tille & Leiognathus smithursti \\
\hline Cheillinus undulatus & Lethrinus decussatus \\
\hline Cephalopholis leopardus & Lethrinus elongatus \\
\hline Cephalopholis sexmaculata & Lethrinus harak \\
\hline Chaetodon subfasciatus & Lethrinus lentjan \\
\hline Coryphaena hippurus & Lethrinus mahsena \\
\hline Chaetodon unimaculatus & Lethrinus microdon \\
\hline Cyoselurus opisthopus & Lethrinus miniatus \\
\hline Crangoides ferdau & Lethrinus nebulosus \\
\hline Decapterus kuroides & Lethrinus nematocanthus \\
\hline Decapterus macarellus & Lethrinus ornatus \\
\hline Decapterus macrosoma & Lethrinus rubrioperculatus \\
\hline Diagramma pictum & Liza vaigiensis \\
\hline Diodon liturosus & Lutjanus argentimaculatus \\
\hline Dussumeiria acuta & Lutjanus bitaeneatus \\
\hline
\end{tabular}

\begin{tabular}{|c|c|}
\hline Dussumeiria elopsoides & Lutjanus bohar \\
\hline Drepane punctata & Lutjanus boutom \\
\hline Makaira indica & Lutjanus decussatus \\
\hline Makaira mazara & Lutjanus fulviflamma \\
\hline Mene maculata & Lutjanus isacanthus \\
\hline Megalops cyprinoides & Lutjanus kasmira \\
\hline Monotaxis grandoculis & Lutjanus lutjanus \\
\hline Mugil cephalus & Lutjanus malabaricus \\
\hline Megalaspis cordyla & Lutjanus miniatus \\
\hline Myripristis murdjan & Lutjanus monostigma \\
\hline Naso fageni & Lutjanus biguttatus \\
\hline Naso lituratus & Lutjanus quinquelineatus \\
\hline Naso tuberosus & Lutianus rivulatus \\
\hline Naso brevirostis & Lutjanus russelli \\
\hline Naso annulatus & Lutjanus sebae \\
\hline Naucratic ductor & Lutjanus sanguineus \\
\hline Nemipterus marginatus & Lutjanus vita \\
\hline Nemipterus peronii & Scarus niger \\
\hline Nemipterus nematophorus & Scarus rivulatus \\
\hline Nemipterus bathybius & Scarus tricolor \\
\hline Nemipterus brevirosis & Scarus festivus \\
\hline Nemipterus decussatus & Scarus frenatus \\
\hline Nemipterus furcosus & Scarus ghobban \\
\hline Nemipterus hemorosus & Scarus quoyi \\
\hline Nemipterus hexodon & Scarus sordidus \\
\hline Nemipterus isacanthus & Scarus javanicus \\
\hline Nemipterus japonicus & Scarus forsteri \\
\hline Nemipterus peronii & Scolopsis ciliatus \\
\hline Nemipterus tuberosus & Scolopsis bilineatus \\
\hline Nemipterus virgatus & Scolopsis ghanam \\
\hline Pterocaesio digramma & Scolopsis monogramma \\
\hline Pterocaesio tile & Scolopsis taeniopterus \\
\hline Pterocaesio pisang & Scolopsis xenochrous \\
\hline Plotosus lineatus & Scomberoides tala \\
\hline Platax orbiculatus & Scomberoides lysan \\
\hline Platax pinnatus & Scomberoides tol \\
\hline Parascolopsis eriomma & Scomberomorus commerson \\
\hline Parupeneus heptacanthus & Scomberomorus sanguiliniatus \\
\hline Parupeneus multifasciatus & Scomberomorus guttatus \\
\hline Parupeneus barberinus & Priacanthus macracanthus \\
\hline Pinjalo pinjalo & Pomadasys argebteus \\
\hline Parupeneus bifasciatus & Pomacentrus moluccensis \\
\hline Parupeneus indicus & Rastrelliger faughni \\
\hline Parupeneus spilurus & Rastrelliger brachysoma \\
\hline Pentaprion longimanus & Rastrelliger kanagurta \\
\hline Pentapodus emeryii & Sardinella gibbosa \\
\hline Pentapodus paradiseus & Sardinella albella \\
\hline Plectorhinchus goldmanni & Sardinella brachysoma \\
\hline Plectorhinchus indicus & Sardinella lemuro \\
\hline Plectorhinchus multivitatum & Sardinella fimbriata \\
\hline Plectorhinchus pictus & Scaevius milii \\
\hline Plectorhinchus polytaenia & Scaevius taeniopterus \\
\hline Plectropomus oligacanthus & Sphyraena obtusata \\
\hline Plectropomus punctatus & Sphyraena putnamie \\
\hline Plectropomus areolatus & Stolephorus ronquilloi \\
\hline Plotosus lineatus & Stolephorus commersonii \\
\hline Pseudocaranx dentex & Siganus punctatus \\
\hline Psettodes erumei & Siganus javus \\
\hline Psettodes belcheri & Sphyraena sphyraena \\
\hline Priacanthus tayenus & Sphyraena barracuda \\
\hline Priacanthus hamrur & Saurida longimanus \\
\hline Stolephorus punctifer & Thunnus albacares \\
\hline Stolephorus indicus & Thunnus obesus \\
\hline Sillago sihama & Thunnus tonggol \\
\hline Sillago japonica & Thunnus alalunga \\
\hline
\end{tabular}




\begin{tabular}{|l|l|}
\hline Sillago maculata & Terapon jarbua \\
\hline Sphyraena forsteri & Terapon theraps \\
\hline Sphyraena jello & Tylosurus crocodilus \\
\hline Secutor roconius & Trichiurus gangeticus \\
\hline Selar boops & Trichiurus lepturus \\
\hline Selar crumenopthalmus & Upeneus sulphureus \\
\hline Selaroides leptolipis & Upeneus tragula \\
\hline Siganus argentea & Upeneus vittatus \\
\hline
\end{tabular}

\begin{tabular}{|l|l|}
\hline Siganus canaliculatus & Upeneus moluccensis \\
\hline Siganus vermiculatus & Upeneus bensasi \\
\hline Siganus fuscescens & Urapis urapis \\
\hline Siganus guttatus & Valamugil seheli \\
\hline Siganus lineatus & Xiphias gladius \\
\hline Siganus vulpinus & \\
\hline Siganus spinus & \\
\hline & \\
\hline
\end{tabular}

Table 4. Growth Parameter estimates

\begin{tabular}{|c|c|c|c|c|c|c|}
\hline \multicolumn{7}{|c|}{2009} \\
\hline Species & Loo $(\mathrm{cm})$ & K (yr-1) & $\mathrm{Z}(\mathrm{yr}-1)$ & M (yr-1) & F (yr-1) & E (yr-1) \\
\hline R. kanagurta & 29.35 & 1.03 & 5.14 & 1.83 & 3.31 & 0.64 \\
\hline S. crumenopthalmus & 26.13 & 1.6 & 5.51 & 2.58 & 2.93 & 0.53 \\
\hline D. macrosoma & 23.38 & 0.98 & 3.98 & 1.89 & 2.09 & 0.53 \\
\hline S. lemuru & 22.37 & 1.3 & 5.82 & 2.3 & 3.52 & 0.6 \\
\hline A. thazard & 39.5 & 0.63 & 5.94 & 1.22 & 4.72 & 0.79 \\
\hline \multicolumn{7}{|c|}{2010} \\
\hline Species & Loo $(\mathrm{cm})$ & K (yr-1) & $\mathrm{Z}(\mathrm{yr}-1)$ & M (yr-1) & F (yr-1) & E (yr-1) \\
\hline R. kanagurta & 30.55 & 0.96 & 2.89 & 1.73 & 1.16 & 0.4 \\
\hline S. crumenopthalmus & 25.81 & 1.54 & 8.82 & 3.43 & 5.39 & 0.61 \\
\hline D. macrosoma & 23.4 & 1 & 5.56 & 1.91 & 3.65 & 0.66 \\
\hline S.lemuru & 20.62 & 0.85 & 3.64 & 1.78 & 1.86 & 0.51 \\
\hline A. thazard & 46.66 & 0.87 & 6.31 & 1.44 & 4.87 & 0.77 \\
\hline \multicolumn{7}{|c|}{2011} \\
\hline Species & Loo $(\mathrm{cm})$ & K (yr-1) & $\mathrm{Z}(\mathrm{yr}-1)$ & $M(y r-1)$ & F (yr-1) & $\mathrm{E}(\mathrm{yr}-1)$ \\
\hline R. kanagurta & 29.76 & 0.8 & 4.4 & 1.55 & 2.85 & 0.65 \\
\hline S. crumenopthalmus & 27.64 & 0.87 & 5.18 & 1.67 & 3.51 & 0.68 \\
\hline D. macrosoma & 27.23 & 0.55 & 2 & 1.24 & 0.76 & 0.38 \\
\hline S.lemuru & 24.04 & 0.97 & 3.74 & 1.86 & 1.88 & 0.5 \\
\hline A. thazard & 33.86 & 0.73 & 3.37 & 1.42 & 1.95 & 0.58 \\
\hline
\end{tabular}

\section{Mortality}

Estimates of the mortality values of the selected species are shown in the above tables. Total Mortality $(\mathrm{Z})$ is the sum of fishing mortality (F) and natural mortality (M). Natural mortality is the mortality created by causes other than fishing (e.g., predation, disease, spawning stress, starvation, and old age). The same species may have different natural mortality in different areas depending on the density of predators and competitors whose abundance is influenced by fishing activities (Sparre and Venema 1992).

In this paper, we are more concerned about fishing mortality as this is a situation that human intervention can be injected. Thus, total mortality $(Z)$ is estimated using the empirical formula of Pauly (1984):

$$
\log M=0.654 \log k-0.28 \log L_{\infty}+0.463 \log T
$$

where $\mathrm{L}_{\infty}$ and $\mathrm{k}$ are the VBGF growth parameters and $\mathrm{T}$ is the annual mean habitat temperature $(\mathrm{oC})$ of the environment wherein the fish stock being the subject of the study lives. When the value of fishing mortality $(\mathrm{F})$ and natural mortality $(\mathrm{M})$ is known, we can, therefore, compute the value of Exploitation rate. This is essential as it would give us the fishing condition of a certain area. Exploitation rate is then computed using the ratio of fishing mortality $(\mathrm{F})$ over total mortality $(\mathrm{Z})$; thus: $\mathrm{E}=$ $\mathrm{F} / \mathrm{Z}$.

Ideally, an estimate of the value of exploitation rate should be $\mathrm{E} \leq 0.5$, otherwise, an estimate of $\mathrm{E}$ value, i.e. $\mathrm{E}>0.5$ represents overexploitation of a fish.

Figure 8 shows the graphical illustrations of the E-values of the selected small pelagic species. Decapterus macrosoma had exceeded the optimum level of exploitation in 2009, 2010, and 2012 with the highest E-value of 0.65 in 2010. The highest E-value of Decapterus macrosoma in 2010 relates to the highest catch rate of commercial and municipal gears in the same year (Figures 2 and 3). Auxis thazard exceeded the optimum level from 2008 to 2011 with the highest E-value of 0.8 in 2009. The highest E-value of Auxis thazard in 2009 relates to the highest catch rate attained by HL and MHL in the same year. Selar crumenophthalmus exceeded the optimum level from CY 2008-2012 with the highest E-value of 0.7 in 2011. Sardinella lemuru exceeded the optimum level in 2008, 2009, and 2012 with the highest value of 0.65 in 2012. Rastrelliger kanagurta exceeded the optimum value in 2008, 2009 and 2011 (highest E-value). 


\section{The Philippine Journal of Fisheries 25 (1): 183-192}

When a fish species exceeds the optimum level of E-value, it connotes that heavy fishing pressure was inflicted on that particular species which, if no management intervention is applied, may cause an unfavorable situation to the biomass as a whole.

While there are fish species like sardines which are capable of replenishing their population because of their robust reproduction, thus can withstand a higher degree of exploitation, still, an effective fisheries management is of utmost necessity because any continued and unregulated fishing activities can be detrimental to fish populations in the long run.

\section{S U M M A R Y}

According to the number of monitored commercial and municipal gears, ring net had the highest count followed by bag net. For municipal gears, drift gillnet had the highest count for this sector, this was followed by gillnet, hook and line, and multiple hook and line.

For the landed catch data of small pelagic species caught by ring net and bag net, it was observed that while the catch for Selar crumenophthalmus, Rastrelliger kanagurta, and Auxis thazard decreased, the catch for Decapterus macrosoma and Sardinella lemuru increased. The sardine close season in the Zamboanga Peninsula is believed to have influenced the high catch rate of Sardinella lemuru in 2010 to 2012.

Catch per unit effort of ring net, bag net, drift gillnet, gillnet, hook and line, and multiple hook and line showed a continuous decline from 2009 to 2012.

Tuna and tuna-like species dominate the catch composition and relative abundance of fishes caught in Basilan, Sulu, and Tawi-Tawi (BASULTA). Most of the tuna catches were recorded in the province of Sulu. This can be concluded that Sulu is home to tuna and tuna-like fishes.

Exploitation values of the species analyzed showed that they had exceeded the optimum level of exploitation ratio. This is another indication, in addition to the declining CPUE of the major commercial and municipal gears, that the fishing area of BASULTA, which is a portion of the Sulu Sea, is experiencing exploitation or heavy fishing pressure, which, if not properly address may lead to a more serious problem.

\section{REFER E N C E S}

BFAR Regional Office - ARMM. National Stock Assessment Project (NSAP) files, 2008-2012. BFAR-
ARMM, ORG Compound, Cotabato City.

Beverton RJH, Holt SJ. 1956. A review of methods for estimating mortality rates in exploited fish populations, with special references to sources of bias in catch sampling. Rapp. P.-v. Reun. CIEM 140: 67-83.

Brey T, Pauly D. 1986. Electronic Length Frequency Analysis: a revised expanded user's guide to ELEFAN 0, 1 and 2. Ber. Inst. Meereskd. ChristianAlbrechts-Univ. Kiel 149: 76.

Carpenter KE, Springer VG. 2005. The center of the center of marine shore fish biodiversity: the Philippine Islands. Environmental Biology of Fishes 72(4): 467-480. https://doi.org/10.1007/S10641-004-31544.

Froese R, Pauly D, editors. 2004. Fish Base 2004: concept, design, and data sources. International Center for Living Aquatic Resources Management (ICLARM).

Gayanilo FC Jr, Sparre P, Pauly D. 1996. FAO-ICLARM Stock Assessment Tools (FISAT): User's Manual.

Gayanilo FC, Pauly D, editors. 1997. FAO-ICLARM Stock Assessment Tools (FISAT). Reference Manual. FAO Computerized Information Series (Fisheries) No. 8. FAO. Rome. http://www.fao.org/dorcep/009/ y5997e/y5997e00.HTM

Herre AWCT. 1953. Check list of Philippine fishes. Res. Rep. U.S. Fish Wild. Serv., 20: 977.

ONEOCEAN. 1998. FISH Project. Philippines. [date updated: 14 January 2011]. http://www.oneocean. org/flash/philippines_biodiversity.html/\#herre 53

Pauly D. 1984. Fish population dynamics in tropical waters: a manual for use with programmable calculators. ICLARM Studies and Reviews 8: 325.

Sparre P, Venema C. 1992. Introduction to tropical fish stock assessment - Part 1: Manual. FAO-Fisheries technical paper. No. 306.1, Rev.1, FAO. p. 376. 